\title{
CORPORATE CULTURE AND THE CHANGING OF TOURISM IN MAEHONGSON
}

\author{
Krit Phanpanya \\ Mae Hong Son College, Chiang Mai Rajabhat University, Thailand
}

\begin{abstract}
Nowadays structure changing such as political structure from the top to the bottom has a strong impact on changing of Maehongson culture. It is because of the policy and strategy of the powerful people who are usually from other provinces and cultures. Their cultures, which are some similar but most are so different, are usually brought to apply in Maehongson. Education, immigrant from Myanmar, moving for study or work in big city such as Chiangmai, Bangkok, marriage and modern technology are other causes that affect the traditional and way of life in Maehongson. Taking standard corporate culture into daily life or receiving news and information without any consideration may interfere and fade away Maehongson cultural capital and tourism which has long history and at the moment has strong tradition. In summary, taking modern corporate culture both managing and staff selecting are very important in order to manage people who work in Maehongson. If they use the strategy in the good deed for example setting the seminar to train staff to have an understanding on Maehongson culture, people and their way of life including their language, believe, cloths or their community relationship, it will be a positive changing for Maehongson. Otherwise, the negative effect will be shown up. The management should not be TopDown strategy. The integrated policy from rural people, Maehongson people, should be considered to reach the real requirement of them.
\end{abstract}

Keywords: corporate culture; changing on Maehongson tourism

\section{INTRODUCTION}

Mae Hong Son Province is approximately 924 kilometers. North of Thailand's capital city Bangkok. To the north and west it connects to a total of three states in the Union of Burma, namely the southern portion of Shan State, Kayah State, and Kawthoolei State, These formations serve as natural boundaries between the countries. To the south, it connects to the district of Tha Song Yang and Tak, which serve as a provincial boundary. To the east it connects to the districts of Wiang Haeng, Chiang Dao, MaTaeng, Maehaem, Hot and Omkoi in Chiang Mai Province, which serve as a boundary between the two provinces. The impact of technology and modernization currently have been affective the social structure. The impact of infrastructure on growth in developing countries. There is more technical evident that better quantity and quantity of infrastructure can directly raise the productivity of human and physical capital and hence growth by providing access, road can, improve education and market for farmer's outputs, facilitate private investment, improve jobs and income level for many.
It is because of the policy and strategy of the powerful people who are usually from other provinces and cultures. In Maehongson, it have been to respond to expressed spiritual inherit long history culture. However, it is not yet clear how the changing of tourism and what is the impact on changing of Maehongson culture.

The purpose of this study was to clarify structure changing such as political structure and what is the impact on changing of tourism in Maehongson. In this study, Education, immigrant from Myanmar, moving for study or work in big city such as Chiangmai, Bangkok, marriage and modern technology are other causes that affect the traditional and way of life in Maehongson regarding the theory of structural function and behavior change. 


\section{THE STUDY /METHODOLOGY}

Subject were recruited for a qualitative descriptive study entitled, Empical research in influence of organizational culture on leadership was conducted in the period February- October 2015 on a sample of 248,178 populations in 7 districts. A total of 400 questionnaires were distributed of which Element Development Organization. The natural beauty of the reporting style of the organization. And the success of the Organization, as well as the effect of changing cultural tourism Chong Hong. Thai people who worked in Maehongson reported positive receiving and negative receiving in culture. The changing of tourism in Maehongson were then interpreted by an investigator using policy from government and CBT community base tourism. Maehongson province has vision "the city of ecotourism open the gateway to. The west, The sustainable economic development "7 districts 44 sub districts and 415 villages. 248,174 population and growth rate $0.66 \%$ Population density total 19.24 per sq.km. Population from registration record 5 unknown 19,369 a non-thai national 475 Transferring population 1,791 population registered. In central house file. According to the Provincial Performance Management System Manual Fiscal Year 2013 by grouping the proposals for changes to create transparency practice, Mae Hong Son province was ranked 20th in the country. In the registration process of identity card, a request for the first time of identity cards (Thai children of completed age of 7 years old), it affects toward the changes of high population and the operations of the governmental organizations very efficiently. As for the study of the primary data in the dimension of organization development of year 2011, the achievement level of quality management development of the government sector by 20 percent or an average of 4.2724 which is classified as a percentage of 8.00 of the quality criteria of public administration degree or an average of 3.1833. The achievement level of the weighted average percentage to achieve successful results of the performance of the province on the basis of quality management of the public administration at the basic level is at 6.00 or an average of 4.9969. The achievement level of organizational self-assessment based on the guidelines of the quality development of public administration at the basic level is at $\mathbf{6 . 0 0}$ on an average of 5.0000 in the year of 2012. Besides, the achievement level of the quality management of the public administration by 20 percent or an average of 4.1435. In the year of 2013 the assessment method used for improving the cultural organization composes of 1. Consistency within the organization such as Direction of the organization, Leadership and Climate 2. Success of the Organization such as Coordination, Control, Motivation, Accountability and Teamwork 3. New Creation of External Orientation and Innovation and Learning. The indicators of the achievement level of development of the cultural organization are divided into 2 subindicators as follows: 1. the difference between opinion and importance towards the satisfaction in improving the cultural organization, its value score is 0.0750 2. The achievement level of a plan for improving the cultural organization, its value score is 0.0750. In the year of the 2014, the competency development of the organization (human capital information technology and cultural organization) is a continuation of the internal corporate management system as a mechanism for creating a highly efficient organization. It contains $\mathbf{3}$ main aspects include Human Capital, Information Capital and Organization Capital in order to enhance the operation of the organization, which would result in an effective performance of the organization. It causes the working efficiency to meet the objectives of the organization, expectations and needs of service users. The success of the competency development of the organization, the assessment indicators are divided into 2 sub-indicators; the achievement level of the reporting of the organization's characteristics, using the guidelines to improve the operation of the province on the basis of Public Sector Management Quality Award (PMQA) and the achievement level of the development organization, using an Organization Development Survey which has 2 assessment that is Pre-Test and Post-Test. The questions are composed of three areas as follows: 10 questions from Human Capital Area; it focuses on policies and goals for human resource management, communication, task assignment, job progress, and development, 6 questions from Information Capital Area and 14 questions from Organization Capital.

\section{RESULT/RESEARCH FINDINGS}

In 2015, the tourism situations of Mae Hong Son province, there are tourists travelling into the city for 
890,159 people in total. It has been increased from last year for 11.40 percent. This can be divided $56.46 \%$ for Thailand tourists and $43.54 \%$ for foreign tourists. As for the average occupancy rate throughout the year, it is $35.76 \%$. It decreased for $0.48 \%$ when comparing to last year. The revenue from tourism is about 5, 996.22 million baht. While the areas of Pai District, there are 579,209 people, representing all tourists travelling in Mae Hong Son province and its revenue from the tourism is 2,689 million baht. Pai District has a growth rate of tourists, especially Chinese tourists with more than $30 \%$ which is ranked to the number 1 instead of tourists.

Most came from the city of Chengdu, and Beijing, which is a group of Gen-Y tourists that have moderate to high purchasing power. Most working age group and couples can communicate in English from low to medium level. As for the family group, they will be travelling in a form of caravan from Yunnan from Yunnan Province crossing the border into Thailand through Chiang Rai and Chiang Mai and they continue their journey into Pai District. As for the habit characteristics of Chinese tourists, they focus on good accommodation delicious food and good photo corner whereas F.I.T tourists they will travel by public vans into Pai District and rent motorcycles to tour around Pai. They go sight-seeing and take pictures in tourist attractions, restaurants, coffee shops, and do some soft adventure activities, including elephant riding, rafting, etc.

The tourist business entrepreneurs in Pai District have adapted themselves based on the flow of Chinese tourists by adding tour programs by the needs of Chinese tourists, including accommodation and restaurant as well as Chinese labels and they have received a good response from Chinese tourists as well.

\section{CITATIONS}

To provide for an effective performance, the policy of good governance organization of Mae Hong Son has determined the practice principles as follows:

1. Communicate to all personnel to know and understand about the policy thoroughly.
2. Systemize the good governance effectively to ensure that the personnel and the organization will behave according to the policy of good governance organization strictly.

3. Expect everyone to report honestly about the unusual or suspected of the policy to the supervisor directly. If they cannot report directly to their supervisors, they may ask for suggestions from the executives or Mae Hong Son Provincial Office and that information should be confidential. However, the supervisors are responsible to monitor and give suggestions to their subordinates to follow the policy of good governance organization.

4. The policy of good governance organization should be improved annually by Mae Hong Son Provincial Office.

5. The province should determine the guidelines for measurement and assessment of the good governance organization based on the indicators systematically.

\section{PROBLEMS AND OBSTACLES}

The operation of the good governance organization policy of Mae Hong Son province is the good management system according to the principles of good governance. It is effective, transparent and it can be investigated with an acceptable standard to all parties. Importantly, the satisfaction of the people under the framework, vision and mission of Mae Hong Son province, which contains the policies and practices under the four main policies of 4 areas; policy of state, social and environment, administrators and the stake holders, organization and performers. Overall, the people have received the cooperation of the relevant authorities as well. However, there are some people who have not been conducted in accordance with the good governance policy organization from Mae Hong Son province perfectly. It may cause from the administrators do not understand the policy clearly so they are not aware of their duties and responsibilities or they understand that they are not responsible directly so it is not pushed for the implementation of all four aspects concretely. 
Table 1 Graph of growth indications of Mae Hong Son.

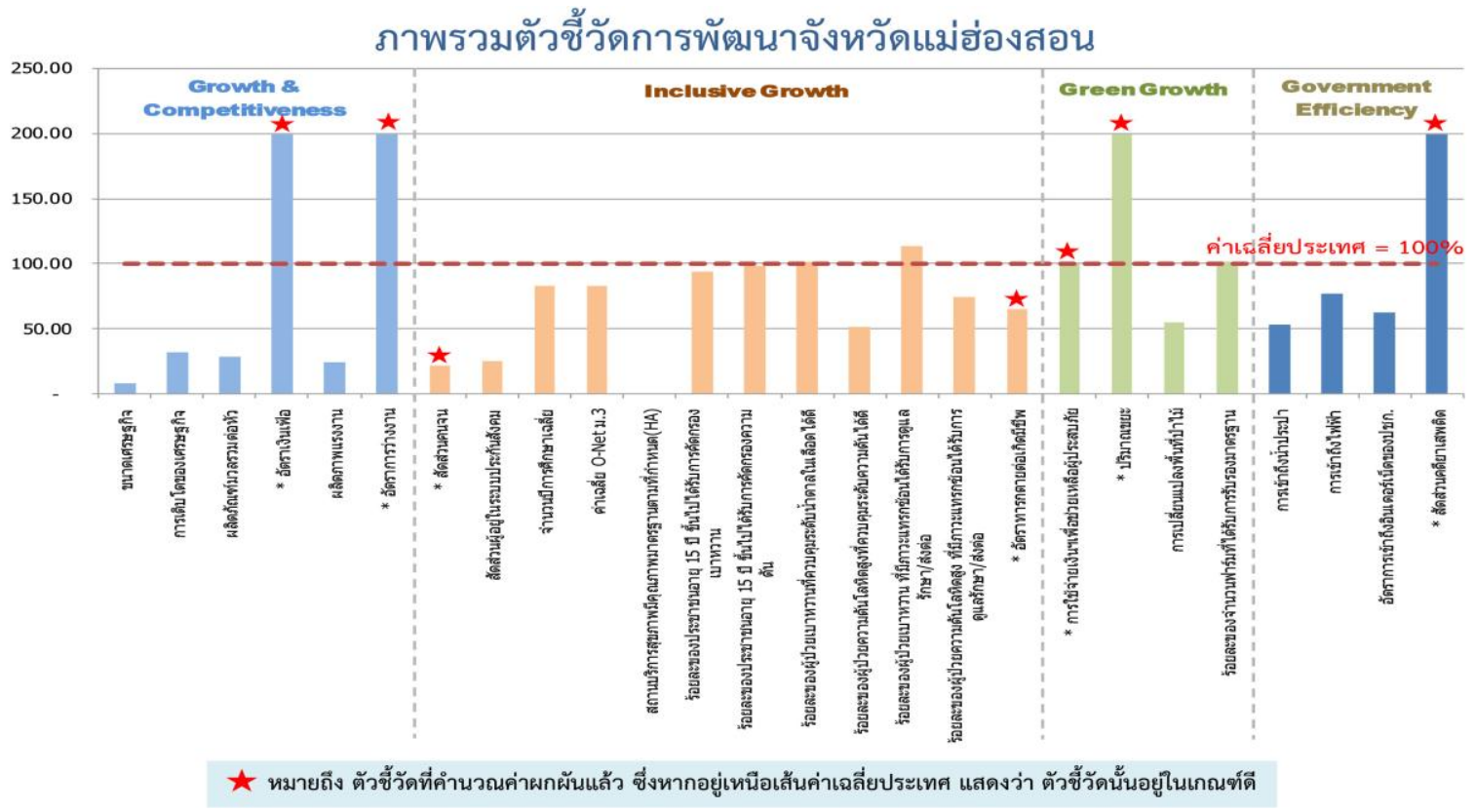

Table 2 Table of growth indications of Mae Hong Son.

ข้อมูลประกอบการอ่านกราฟภาพรวมตัวชี้วัดของจังหวัดแม่ฮ่องสอน

\begin{tabular}{|c|c|c|c|c|}
\hline & ประเทศ & แม่ฮ่องสอน & หน่วย \\
\hline \multirow{6}{*}{ 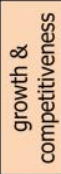 } & ขนาดเศรษฐกิจ & 102,491 & 8,843 & ล้านบาท \\
\hline & การเดิบโดของเศรษฐกิจ & 3.1 & 1.0 & ร้อยละ \\
\hline & ผลิดภัณฑ์มวลรวมด่อหัว & 128,245 & 37,456 & บาท/ปี \\
\hline & * อัดราเงนเฟ้อ & 3.0 & 0.9 & ร้อยละ \\
\hline & ผลิตภาพแรงงาน & 158,395 & 38,997 & บาท/คน (ปรับ 6 กย56) \\
\hline & * อัดราการว่างงาน & 0.66 & 0.20 & ร้อยละ \\
\hline \multirow{12}{*}{ 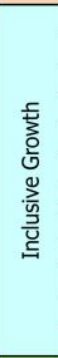 } & * สัดส่วนคนจน & 13.15 & 60.29 & ร้อยละ \\
\hline & สัดส่วนผ้อยู่ในระบบประกันสังคม & 26.98 & 6.89 & ร้อยละ (ปรับ 6 กษ 56 ) \\
\hline & จำนวนปีการศึกษาเฉลี่ย & 9.1 & 7.6 & ปี \\
\hline & ค่าเฉลี่ย O-Net ม.3 & 50.00 & 41.46 & ร้อยละ (ปรับ 6 กย 56 ) \\
\hline & สถานบริการสขภาพมีคณภาพมาตรฐานดามที่กำหนด $(\mathrm{HA})$ & 25.99 & 0.00 & ร้อยละ \\
\hline & ร้อยละของประชาชนอาย 15 ปี ขึ้นไปได้รับการคัดกรองเบาหวาน & 36.93 & 34.67 & ร้อยละ \\
\hline & ร้อยละของประชาชนอาย 15 ปี ขึ้นไปได้รับการคัดกรองความดัน & 39.86 & 39.33 & ร้อยละ \\
\hline & ร้อยละของผู้ป่วยเบาหวานที่ควบคุมระดับน้ำดาลในเลือดได้ดี & 3.71 & 3.78 & ร้อยละ \\
\hline & ร้อยละของผู่ป่วยความดันโลหิดสงที่ควบคุมระดับความดันได้ดี & 4.19 & 2.16 & ร้อยละ \\
\hline & ร้อยละของผู้ป่วยเบาหวาน ที่มีภาวะแทรกซ้อนได้รับการดแลรักษา/สงต่อ & 75.67 & 86.18 & ร้อยละ \\
\hline & ร้อยละของผ้ป่วยความดันโลหิดสง ที่มีภาวะแทรกซ้อนได้รับการดแลรักษา/ส่งต่อ & 80.60 & 60.0 & ร้อยละ \\
\hline & * อัดราทารกตายต่อเกิดมีชีพ & 6.8 & 10.4 & อัตราทารกตาย/เกิดมีชีพพันคน \\
\hline \multirow{4}{*}{ 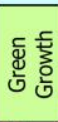 } & * การใช้จ่ายเงินฯเพื่อช่วยเหลือผู้ประสบภัย & $269,688,442$ & $269,739,086$ & บาท \\
\hline & * ปริมาณขยะ & 167,276 & 45,078 & ตัน/ปี \\
\hline & การเปลี่ยนแปลงพื้นที่ป่าไม้ & 2.26 & 1.25 & $\%$ เปลี่ยนแปลงปี 47-51 \\
\hline & ร้อยละของจำนวนฟาร์มที่ได้รับการรับรองมาตรฐาน & 45.10 & 46.07 & ร้อยละ \\
\hline \multirow{4}{*}{ 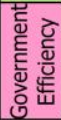 } & การเข้าถึงน้ำประปา & 20.41 & 10.93 & ร้อยละ \\
\hline & การเข้าถึงไฟฟ้า & 99.20 & 76.84 & ร้อยละ \\
\hline & อัตราการเข้าถึงอินเตอร์เน็ดของปชก. & 23.40 & 14.61 & ร้อยละ \\
\hline & * สัดส่วนคดียาเสพดิด & 338.6 & 27.8 & อัตราคดียาเสพดิด/ประชากรแสนคน \\
\hline
\end{tabular}


Table 3 Number of Thai and Foreign visitors in Maehongson Year 2014-2015.

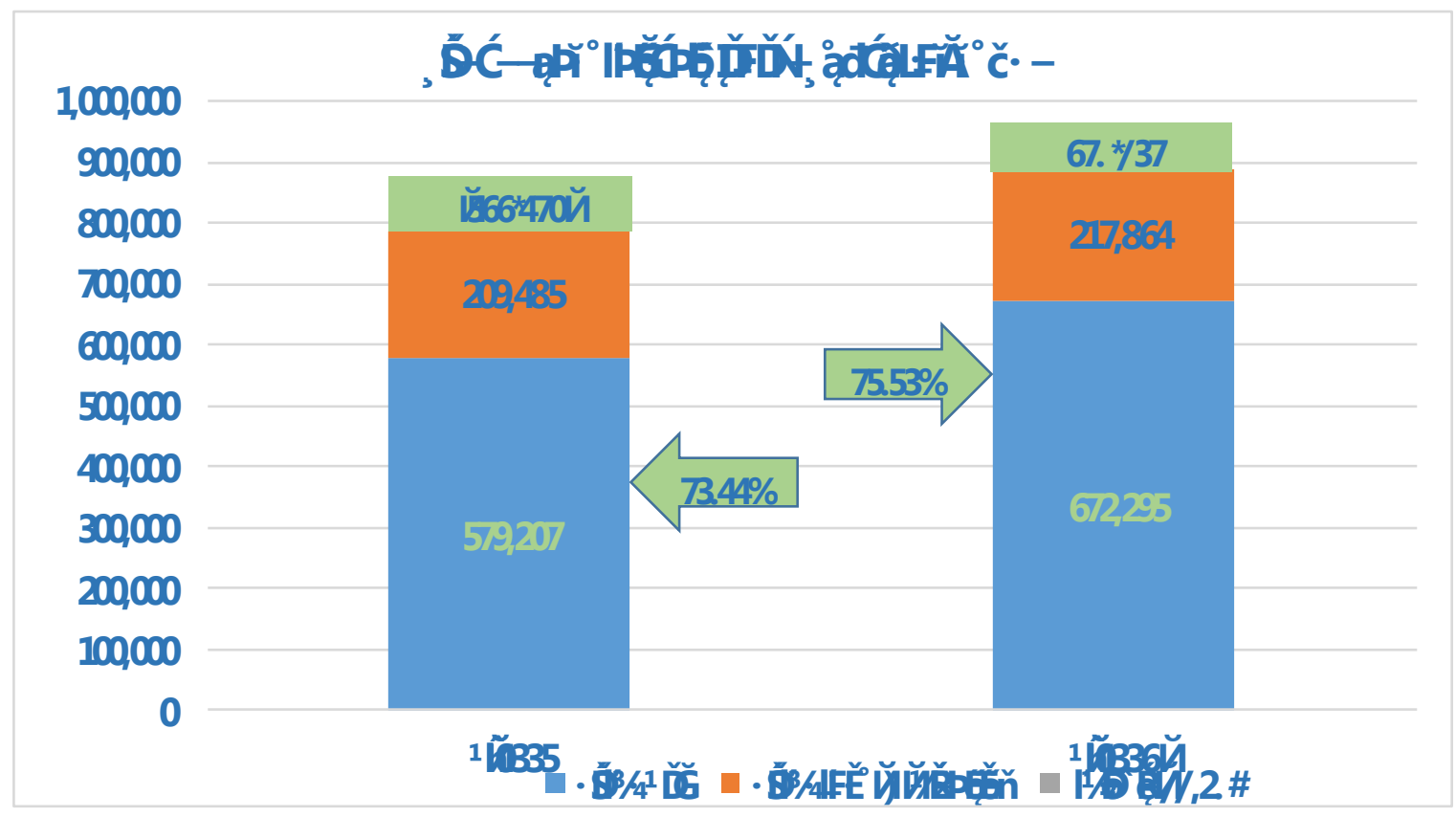

Table 4 Number of Thai and Foreign visitors in Maehongson 2014-2015

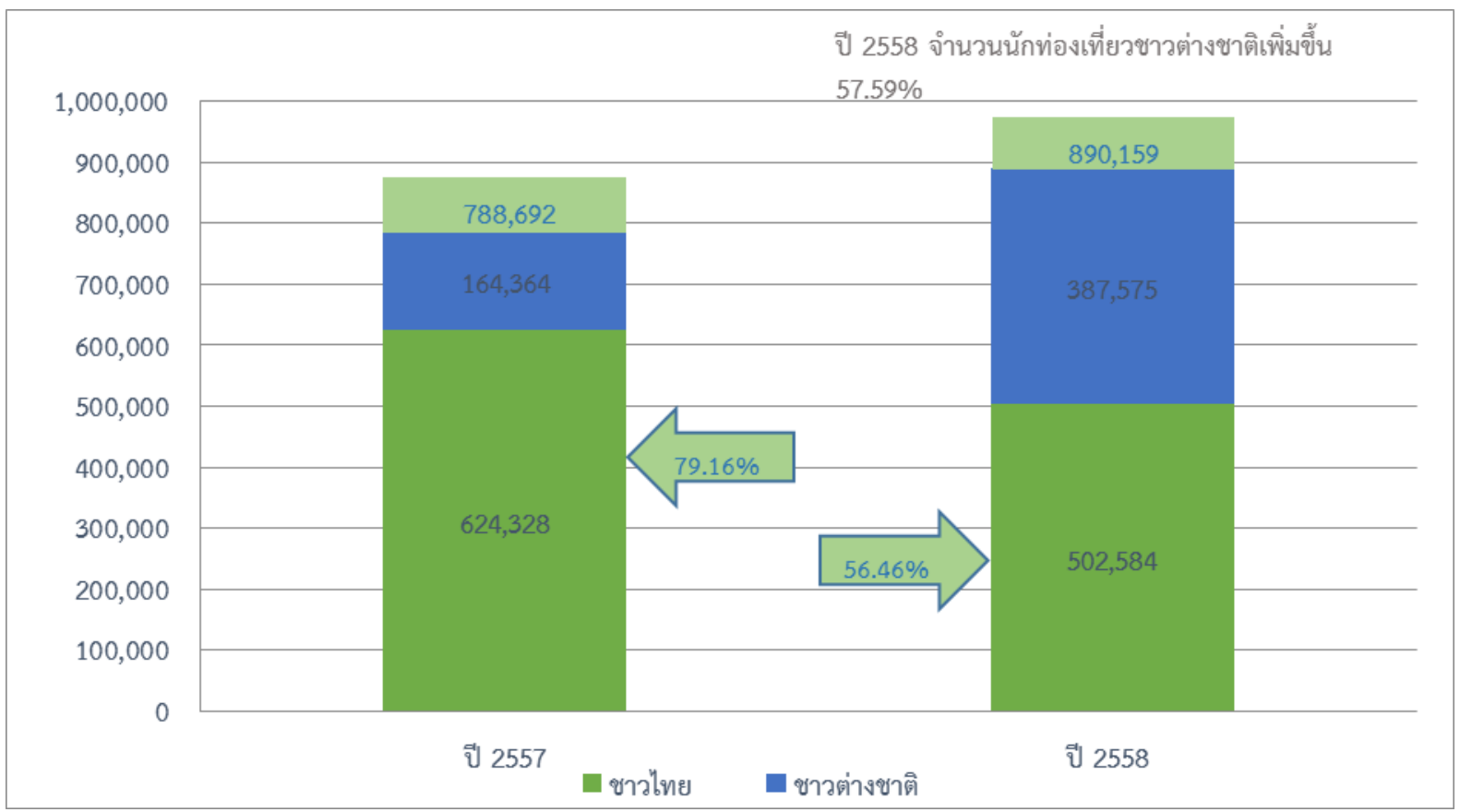


Table 5 Thai and Foreign visitors comparing between 2008-2015

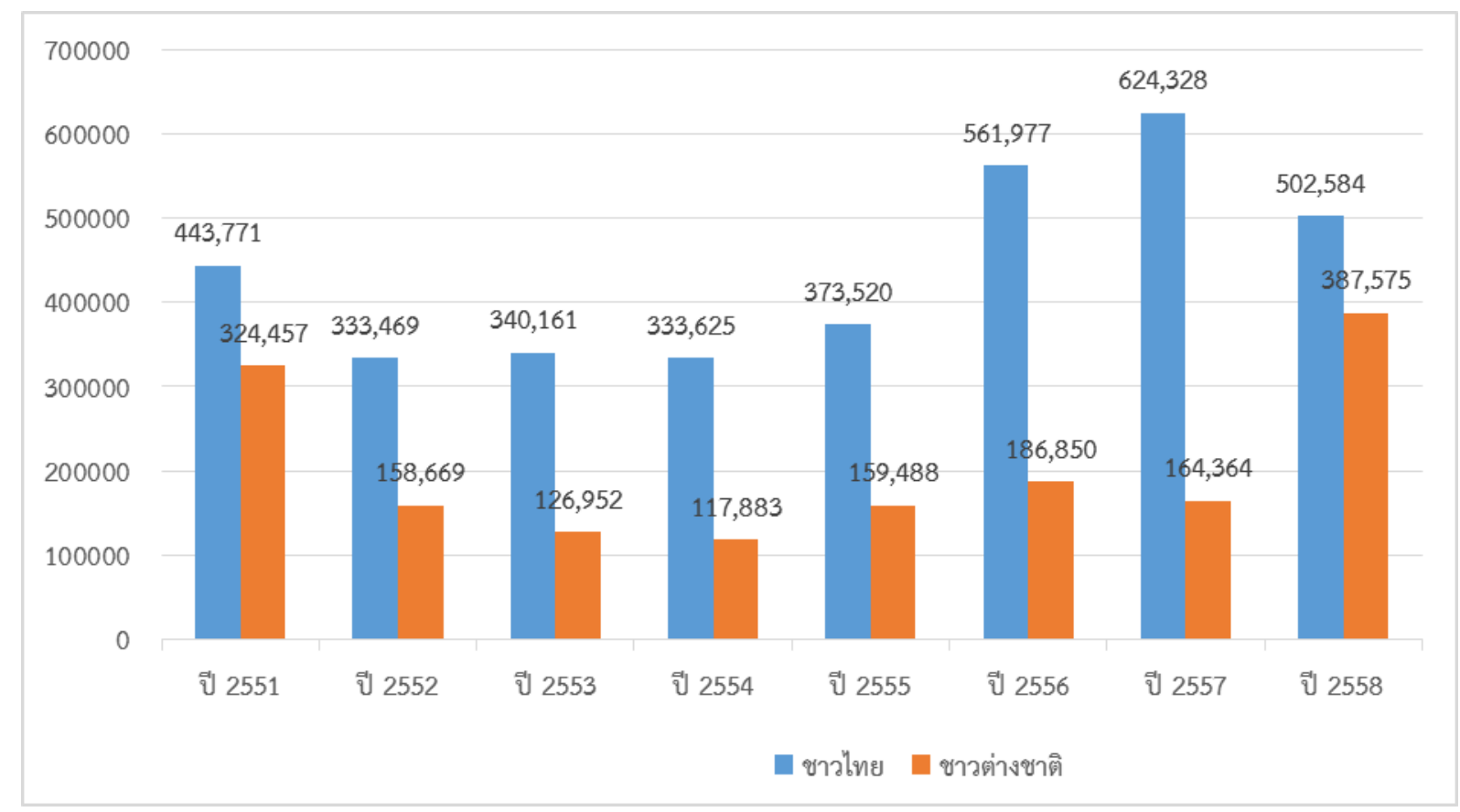

Table 6 Thai and Foreign visitors income comparing between 2014-2015

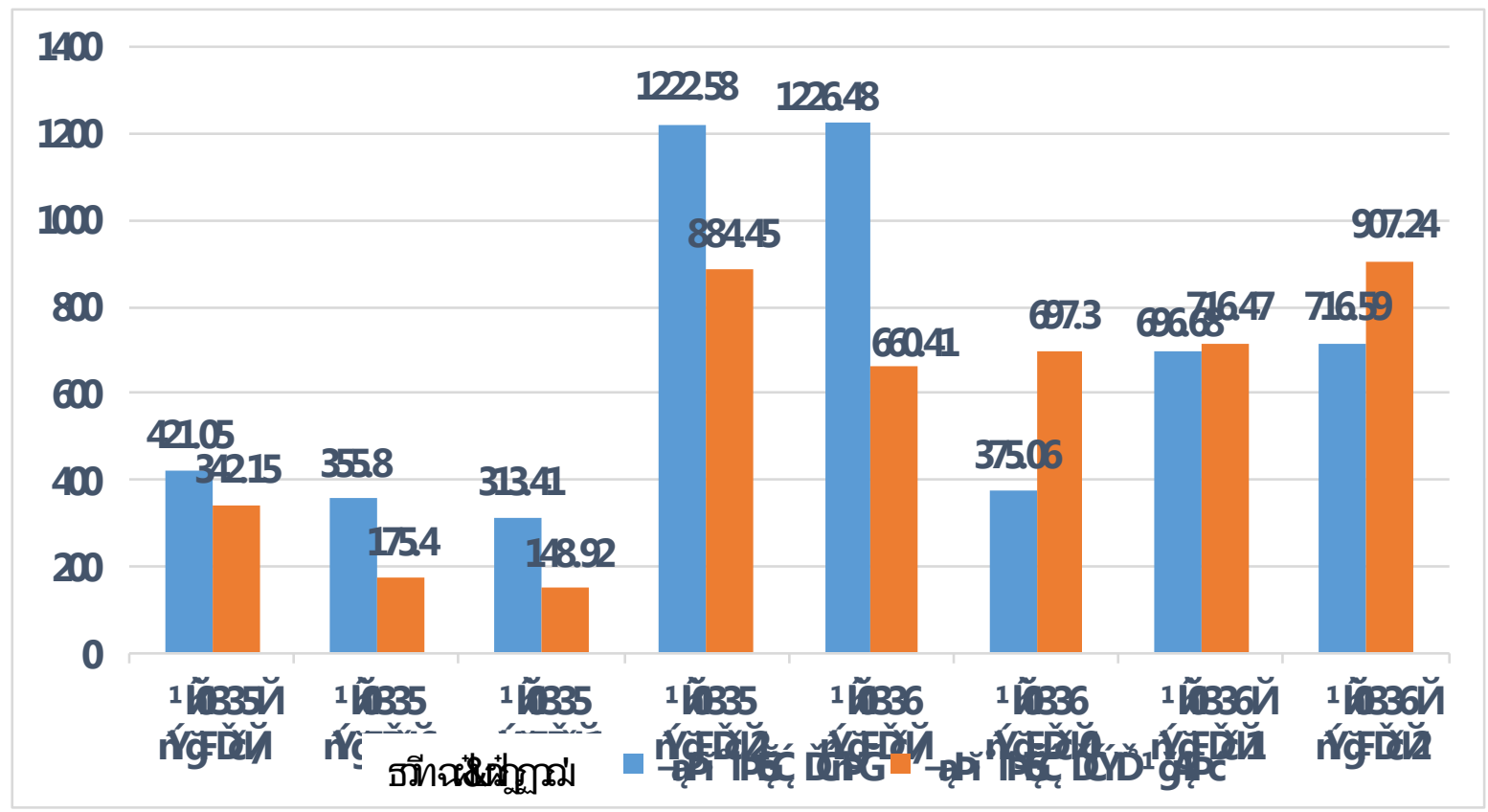


Table 7 Thai and Foreign Visitors income comparing between2008-2015

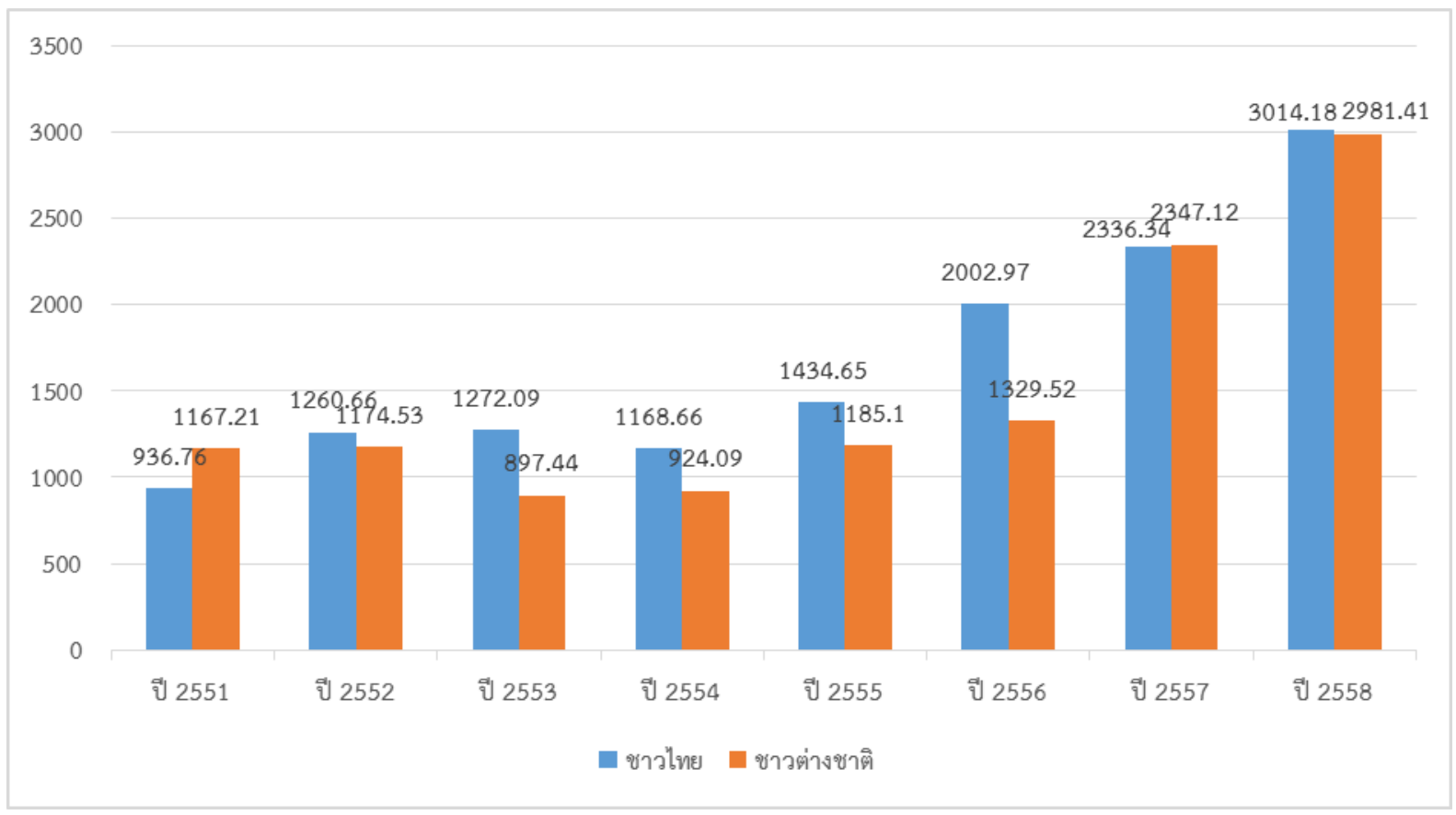

\section{SUGGESTIONS}

The policy of good governance organization. Mae Hong Son province, the policy of the government agencies under a good management system. According to the principles of good governance Effective Transparent verified with a standard acceptable to all parties. And what is the most important the satisfaction of the people Under Vision and mission of Mae Hong Son This includes policies and guidelines under the four main policy areas of state policy. Social and environmental. The recipient of the organization and stakeholders and practitioners. Overall, the cooperation of the relevant authorities as well. But there are some who have not been conducted in accordance with regulatory policy organization of Mae Hong Son. In its entirety, it is because the management has an understanding of regulatory policy error Organization. Not aware of the importance or do not understand their role or understand the mission of the agency is not directly involved. He did not have to push for the implementation of all four sides with a concrete suggestion. The regulatory policy organization of Mae Hong Son. Be treated effectively even better. Should executives be aware and pay attention? Due to the important role of the executive. To be responsible for protecting the interests of all stakeholders. The administrators will be able to push policies to accomplish something tangible. The policy will be published Mae Hong Son province in the People's social teaching has been widely acknowledged. In order to understand and to focus even more.

\section{REFERENCES}

Nuchudee Chaisatit, Virginia R.Matrinez Hernandez, 2016, Tourism Sustainable and Natural Resource Management in Community of San Pedro, Vol:1 Issue:1, 339-353.

Yulan Yuan, Yuen-Hsien Tseng, Chaang-luan Ho, 2016, Knowledge Base and Flow of Major Tourism and Hospitality Journals, Vol:1 Issue:1, 354-372.

Nuchudee Chaisatit, Jesus Otoniel Sosa Rodriguez, Lilia Itzel Sosa Argaez, 2015, Community Tourism and Local Participation as a Development Strategy for the Rural Communities in Manzanillo, Colima, Maxico, Vol:1 Issue:1, 275-285.

Gordana Nikcevic, The Influence of Organizational Culture on Leadership-Case Study Montenego, 2016,Tennicki vjesnik 23, 191-197.

Ante Glavas, Corporate Social Responsibility and Organizational Psychology:An Intergrative Review, 2016, Frontiers in Psychology, Vol:7, 1-13

Nicolas A. Fisichelli, Gregor W.Schuurman, William B. Monahan, Pamela S.Ziesler, Protected Area 
Tourism in a Changing Climate: Will Visitation at US National Parks Warm up or Overheat?, 2015, Plos One, $1-13$

Reyaz Ahmad Dar, Irfan Rashid, Shakil Ahmad Romshoo, Asif Marazi, Sustainability of winter tourism in a changing climate over Kashmir Himalaya, 2014, Environ Monit Assess, 186:25492562.

Len M.Hunt, Brian Kolman, and Peter Boxall, Assessing the changing effects of forest harvesting on nature-based tourism: a case of sport-fishing tourism in Ontario,Cannada, 2013, Can.J.For.Res.43:171-179.

Burcu Pehivanoglu, The Changing of Concepts in Tourism Structures, 2011, Design Principles and Practices:An International Journal, Vol:5,Issue 6,351368.

Michael Polonsky, John Hall Vieceli, Lutfi Atay, Ali Akdemir, and Mehmet Marangoz, Using strategic philanthropy to improve heritage tourist sites on the Gallipoli Peninsula, Turkey: community perceptions of changing quality of life and of the sponsoring organization, 2013, Journal of Sustainable Tourism, Vol.21, No.3, 376-395.
Oz, M., Kaya, F.,Ciftci, I., Evalating the Organizational Culture Types of the 5-Star Hotel's in Istanbul in terms of the Cameron \& Quinn Competing Values Model, 2015, Journal of Yasar University, 6684-6691.

Charler R. Goeldner, J.R. Brent Ritchie. , 2009, Tourism: principles, practices, philosophies. Eleventh ed.

Krit Phanpanya, Suriya Somchan, 2013, Guidelines for Hospital Development to Support Health Tourism in Phayao, Thailand, European Journal of Social Sciences Vol:37 Issue 4, 546-558.

Mae Hong Son Provincial Statistical Office, 2015, Provincial Statistical Report: 2015, pp.1-187.

Office of the public sector development commission: OPDC, 2015, the official performance evaluate Manual: The fiscal year 2015. www.opdc.go.th.

Office of the public sector development commission: OPDC, 2014, the official performance evaluate Manual: The fiscal year 2014. www.opdc.go.th.

Office of the public sector development commission: OPDC, 2013, the official performance evaluate Manual: The fiscal year 2013. www.opdc.go.th.

Tourism Authority of Thailand Mae Hong Son Office, Summary report Maehongson the fiscal year: 2016, 2016, 1-5. 